\title{
Phenylpropanoid Pathway Is Potentiated by Silicon in the Roots of Banana Plants During the Infection Process of Fusarium oxysporum f. sp. cubense
}

\author{
Alessandro Antônio Fortunato, Washington Luís da Silva, and Fabrício Ávila Rodrigues
}

Viçosa Federal University, Department of Plant Pathology, Laboratory of Host-Pathogen Interaction, Viçosa, Minas Gerais State, 36570000, Brazil.

Accepted for publication 2 December 2013.

\begin{abstract}
Fortunato, A. A., da Silva, W. L., and Rodrigues, F. Á. 2014. Phenylpropanoid pathway is potentiated by silicon in the roots of banana plants during the infection process of Fusarium oxysporum f. sp. cubense. Phytopathology 104:597-603.

Fusarium wilt, caused by Fusarium oxysporum f. sp. cubense, is a disease that causes large reductions in banana yield worldwide. Considering the importance of silicon $(\mathrm{Si})$ to potentiate the resistance of several plant species to pathogen infection, this study aimed to investigate, at the histochemical level, whether this element could enhance the production of phenolics on the roots of banana plants in response to $F$. oxysporum f. sp. cubense infection. Plants of cultivar Maçã, which is susceptible to $F$. oxysporum $\mathrm{f}$. sp. cubense, were grown in plastic pots amended with $0(-\mathrm{Si})$ or $0.39 \mathrm{~g}$ of $\mathrm{Si}(+\mathrm{Si})$ per kilogram of soil and inoculated with race 1 of $F$. oxysporum $\mathrm{f}$. sp. cubense. The root $\mathrm{Si}$ concentration was increased by $35.6 \%$ for $+\mathrm{Si}$ plants in comparison to the -Si plants, which contributed to a $27 \%$ reduction in the symptoms of

contrast, for the root sections obtained from the $+\mathrm{Si}$ plants treated with Neu's reagent, strong yellow-orange fluorescence was observed in the phloem, and lemon-yellow fluorescence was observed in the sclerenchyma and metaxylem vessels, indicating the presence of flavonoids. For the root sections of the $+\mathrm{Si}$ plants treated with Wilson's reagent, orangeyellowish autofluorescence was more pronounced around the phloem vessels, and yellow fluorescence was more pronounced around the metaxylem vessels, also indicating the presence of flavonoids. Lignin was more densely deposited in the cortex of the roots of the $+\mathrm{Si}$ plants than for the $-\mathrm{Si}$ plants. Dopamine was barely detected in the roots of the $-\mathrm{Si}$ plants after using the lactic and glyoxylic acid stain, but was strongly suspected to occur on the phloem and metaxylem vessels of the roots of the $+\mathrm{Si}$ plants as confirmed by the intense orange-yellow fluorescence. The present study provides new evidence of the pivotal role of the phenylpropanoid pathway in the resistance of banana plants to F. oxysporum f. sp. cubense infection when supplied with $\mathrm{Si}$.
\end{abstract} Fusarium wilt on roots. There was an absence of fluorescence for the root sections of the $-\mathrm{Si}$ plants treated with the Neu and Wilson's reagents. By
Additional keywords: host defense mechanisms, vascular pathogen.
Fusarium wilt, caused by Fusarium oxysporum f. sp. cubense (E. F. Smith) Snyder and Hansen, is a root disease that causes large reductions in banana yield worldwide (39). Xylem vessel colonization by $F$. oxysporum f. sp. cubense arises from fungal penetration into the roots, followed by wilting and yellowing of the leaves due to necrosis of the root tissues at advanced stages of fungal infection $(18,38)$.

Several plant species, especially monocots, when subjected to various abiotic and/or biotic stresses, have been found to benefit from the many positive effects of silicon ( $\mathrm{Si}$ ) (13). The intensities of several soilborne diseases, such as those caused by Pythium ultimum and $P$. aphanidermatum in cucumber, Phytophthora capsici in bell pepper, Ralstonia solanacearum and Fusarium oxysporum f. sp. radicis-lycopersici in tomato, and Cylindrocladium spathiphylli and $F$. oxysporum f. sp. cubense in banana, have been found to be significantly decreased when plants are grown in soil or nutrient solution amended with $\mathrm{Si}(5,8,9,12,18-$ 20,22,25,47).

$\mathrm{Si}$ deposition, in the form of silica gel that later becomes biogenetic opal in cell walls and in the intercellular spaces of

Corresponding author: F. Á. Rodrigues; E-mail address: fabricio@ufv.br

* The $\boldsymbol{e}$-Xtra logo stands for "electronic extra" and indicates that Figures 1, 2, and 3 appear in color online.

http://dx.doi.org/10.1094/PHYTO-07-13-0203-R

(C) 2014 The American Phytopathological Society roots and leaf cells $(27,50)$, is one of the mechanisms explaining $\mathrm{Si}$-mediated resistance to diseases in several crops (13). Increases in the concentrations of phenolics, lignin, and phytoalexins, as well as the rapid and strong activation of some pathogenesisrelated genes, are also involved in the Si-mediated mechanisms of host defense (4-7,42-44).

An increase in the concentration of phenolics during the infection process of many pathogens plays a pivotal role in host defense $(16,19,31,32,37,43,45)$. Important information about how plants respond to pathogen infection can be obtained through a detailed histochemical analysis $(2,11,14,29,40,46)$. Substantial deposition of lignin, flavonoids, dopamine, caffeic esters, and ferulic acid has been histochemically detected in the roots of banana plants of a resistant cultivar during the infection process by the nematode Radopholus similis $(46,48,49)$. Intense deposition of phenolics, especially dopamine, in banana roots infected by F. oxysporum f. sp. cubense has been reported (30). Koga et al. (26) observed that the accumulation of insoluble $\mathrm{Si}$ in the epidermal cells of barley plants infected with Blumeria graminis f. sp. hordei was associated with an increase in the autofluorescence intensity, as a result of phenolics released during the loss of cell wall integrity. Rémus-Borel et al. (41), analyzing fresh transverse sections of wheat leaves from plants amended with Si and infected with $B$. graminis f. sp. tritici using fluorescence microscopy, observed substantial deposition of fluorescent compounds, which were characterized as phenolics. Phenolic compounds, flavonoids, and dopamine are commonly involved in host defense as a preformed chemical barrier that can prevent the penetration 
by soilborne pathogens of the roots of resistant banana cultivars (46).

The objective of this study was to investigate, at the histochemical level, whether Si could enhance the production of phenolics in banana roots in response to infection by $F$. oxysporum $\mathrm{f}$. $\mathrm{sp}$. cubense.

\section{MATERIALS AND METHODS}

Banana seedlings of the susceptible cultivar Maçã, obtained from tissue culture (Multiplanta Tecnologia Vegetal Ltda, Andradas, Minas Gerais, Brazil), were transplanted into plastic pots $(39 \times 25 \times 7 \mathrm{~cm})($ Ecovaso, Jaguariúna, SP, Brazil) containing an Si-deficient typical Acrustox red-yellow latosol collected from the 'Triângulo Mineiro' savanna area in Brazil. The calcium silicate used as the Si source (AgroSilício, Harsco Minerais, Timóteo, Minas Gerais, Brazil), was incorporated into each pot at the rates of $0(-\mathrm{Si})$ and $1.75(+\mathrm{Si}) \mathrm{g} / \mathrm{kg}$ of soil. Calcium carbonate $(40 \%$ $\mathrm{Ca}$, Sigma-Aldrich, São Paulo, Brazil) and magnesium carbonate $\left(\mathrm{MgCO}_{3}\right.$, Sigma-Aldrich, São Paulo) were added to each pot at the rates of 1.19 and $0.48 \mathrm{~g} / \mathrm{kg}$ of soil, respectively, to equilibrate the amounts of $\mathrm{Ca}$ and $\mathrm{Mg}$ with the amounts contained in the pots that received $1.75 \mathrm{~g}$ of calcium silicate. The soil in each pot was watered to field capacity and incubated under greenhouse conditions (temperature of $25 \pm 5^{\circ} \mathrm{C}$ and relative humidity of $65 \pm 5 \%$ ) for 60 days, at an approximate humidity of $75 \%$, until the seedlings were transplanted. The plants were then grown for 60 days in the pots under greenhouse conditions.

The plants were inoculated with a monosporic isolate of $F$. oxysporum f. sp. cubense (race 1 ) using a $2 \times 10^{6}$ conidia $/ \mathrm{ml}$ suspension of $F$. oxysporum f. sp. cubense. Before inoculation, plants from the replications of each treatment were carefully removed from the pots and transferred to brand new empty pots. The roots from each plant were cut off with a sterilized scissor and quickly immersed into 0.5 liter of the conidial suspension for $2 \mathrm{~h}$ (18). After this period, the plants were transferred to their original pots and $10 \mathrm{ml}$ of a conidial suspension was added to the soil surface at $1 \mathrm{~cm}$ from the plants at each pot $(2 \mathrm{ml}$ per plant $)$ to permit the soil infestation with the fungus. The plants were kept under greenhouse conditions at a temperature of $25 \pm 5^{\circ} \mathrm{C}$ and a relative humidity of $65 \pm 5 \%$ during the entire experiment. The root symptoms caused by $F$. oxysporum f. sp. cubense were evaluated 24 and 32 days after inoculation (dai) using the following scale proposed by Mohamed et al. (33): 1 indicates roots without any visible symptoms of necrosis, 2 indicates roots with necrosis, 3 indicates roots with intense necrosis, 4 indicates old roots with necrosis and new roots without any visible symptoms of necrosis, 5 indicates necrosis in old roots and new roots with symptoms, and 6 indicates dead roots. After disease assessments, the roots of plants from each replication for each treatment were collected, washed in deionized water, dried for $72 \mathrm{~h}$ at $65^{\circ} \mathrm{C}$, and ground to pass through a 40-mesh screen using a Thomas-Wiley mill (Thomas Scientific, Swedesboro, NJ). The Si concentration in the roots was determined using a colorimetric analysis on $0.1 \mathrm{~g}$ of dried and alkali-digested tissue (18). The calcium (Ca) concentration was determined using nitro-perchloric digestion and atomic absorption spectrophotometry.

An experiment consisting of two $\mathrm{Si}$ treatments (hereinafter referred to as $-\mathrm{Si}$ and $+\mathrm{Si}$ plants) and two sampling times (24 and 32 dai) was arranged in a completely randomized design with 18 replications (each experimental unit consisted of one pot containing two plants) to evaluate the symptoms caused by $F$. oxysporum $\mathrm{f}$. sp. cubense on roots as well as to determine $\mathrm{Si}$ and $\mathrm{Ca}$ concentrations in the roots. A total of six plants were used at each sampling time (36 plants per experiment). Another experiment following the same experimental design as mentioned above was carried out to obtain the root samples for the histochemical analysis. The experiments were repeated once. Cochran's test for homogeneity of variance (21) indicated that the data from the two experiments used to evaluate the symptoms caused by $F$. oxysporum $\mathrm{f}$. sp. cubense on roots as well as to determine $\mathrm{Si}$ and $\mathrm{Ca}$ concentrations in the roots could be pooled for data analysis. The experiment-treatment interactions were not found to be significant $(P \geq 0.05)$ in comparison to the main effects of the treatments. The data were analyzed by analysis of variance and comparisons of treatment means using Tukey's test or Student's $t$ test $(P \leq 0.05)$ implemented in the SAS statistical analysis software (SAS Institute Inc., Cary, NC).

A total of six roots samples from one plant per replication and treatment were collected at the middle of the radicular system at 24 and 32 dai for the histochemical analysis. Roots samples were also collected from noninoculated plants at 0 dai to serve as controls. The root samples were placed in plastic tubes containing

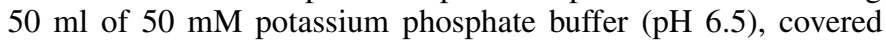
with aluminum foil, and stored at $-20^{\circ} \mathrm{C}$ until further analysis. A total of 30 handmade transverse sections ( 40 to $60 \mu \mathrm{m}$ thick) per root sample were obtained from healthy and infected root samples using a scalpel blade (Lamedid, Jandira, SP, Brazil) at each sampling time. The sections were treated with several reagents in an effort to localize different phenolics. Flavonoids were visualized using Neu's reagent (36). A total of six sections were immersed in a solution made of $1 \%$ 2-amino-ethyldiphenyl-borinate (SigmaAldrich, São Paulo) in absolute methanol for $5 \mathrm{~min}$ and then mounted on glass slides with 2 drops of a glycerine/water solution $(2: 8, \mathrm{vol} / \mathrm{vol})$. Bright lemon-yellow fluorescence indicated their presence on the root tissues. Flavonoids were also detected using Wilson's reagent $(10,11)$. A total of six sections were immersed in a solution of $0.01 \mathrm{M}$ citric acid and boric acid (Sigma-Aldrich, São Paulo) in $100 \mathrm{ml}$ of absolute methanol for $15 \mathrm{~min}$ and then mounted on glass slides with 2 drops of a glycerine/water solution. Yellow fluorescence indicated their presence on the root tissues. The presence of dopamine was detected by immersing six sections in a solution of $0.01 \mathrm{M}$ lactic acid and glyoxylic acid (Sigma-Aldrich, São Paulo) and heated at $100^{\circ} \mathrm{C}$ for $1 \mathrm{~min}$ (46). A yellow color was interpreted as an indicative of the presence of dopamine. Autofluorescence was also monitored on six sections using fluorescence microscopy. All of the transverse sections were examined using a Carl Zeiss Axio Imager A1 microscope with Zeiss filter sets 01 (UV; $365 \mathrm{~nm}$ excitation, $395 \mathrm{~nm}$ beam splitter and $397 \mathrm{~nm}$ emission), 05 (blue; 395 to $400 \mathrm{~nm}$ excitation, $460 \mathrm{~nm}$ beam splitter and $470 \mathrm{~nm}$ emission), and $13(470 \mathrm{~nm}$ excitation, $495 \mathrm{~nm}$ beam splitter and 505 to $530 \mathrm{~nm}$ emission). For lignin detection, a total of six sections were fixed in absolute ethanol and then immersed for $3 \mathrm{~min}$ in a solution of $10 \mathrm{~g}$ of phloroglucinol (Sigma-Aldrich, São Paulo) dissolved in $95 \mathrm{ml}$ of absolute ethanol. The sections were carefully washed in concentrated $\mathrm{HCl}$, mounted on glass slides with 2 drops of a glycerine/ water solution (34), and then observed under bright field microscopy. A red color was interpreted as indicating the presence of lignin or condensed tannins. All digital images were acquired with an AxioCam HRc Rev. 2 and further processed with the AxioVision 4.6 software.

\section{RESULTS}

There was no significant effect of Si rates, sampling times, or their interaction on the $\mathrm{Ca}$ concentration in the roots. The $\mathrm{Si}$ rates and sampling times were significant for the Si root concentration (Table 1). The root $\mathrm{Si}$ concentration was $36 \%$ higher for $+\mathrm{Si}$ plants than for $-\mathrm{Si}$ plants (Table 2). At 32 dai, the Si concentration in the roots was $12 \%$ higher than at 24 dai (Table 2 ).

Only Si rates and sampling times were found to be significant for the symptoms of Fusarium wilt on roots (Table 1). The symptoms of Fusarium wilt on roots were reduced by $27 \%$ for $+\mathrm{Si}$ plants in comparison to the $-\mathrm{Si}$ plants (Table 2). The symptoms of Fusarium wilt were increased by $12 \%$ at 32 dai in comparison to 
24 dai (Table 2). In general, the root symptoms of Fusarium wilt and their effects on the shoots of $+\mathrm{Si}$ plants at 32 dai were dramatically reduced in comparison to the -Si plants as confirmed by lower levels of leaf wilting, yellowing, and leaf and pseudostem tissue necrosis (Fig. 1).

For inoculated plants, intense orange-yellow autofluorescence was detected in the metaxylem and phloem vessels of the root sections of $-\mathrm{Si}$ plants at 24 and 32 dai, respectively (Figs. 2A and $3 \mathrm{~A})$. For the $-\mathrm{Si}$-inoculated plants, the magnitude of the reaction of the cells that exhibited autofluorescence in the medulla and on the cortex was strong, but there was no difference between 24 and 32 dai (Table 3). The autofluorescence of the phloem vessels and the sclerenchyma cells in the root sections of the $+\mathrm{Si}$-inoculated plants at 24 and 32 dai (Figs. 2B and 3B) was lower and the magnitude of the reaction in the medulla and in the cortex was weak (Table 3). For the samples from noninoculated plants, the autofluorescence in the medulla and in the cortex was weak for both the $-\mathrm{Si}$ and $+\mathrm{Si}$ plants. In the samples from noninoculated plants, the cells in the medulla and in the cortex of the root sections of both the $-\mathrm{Si}$ and $+\mathrm{Si}$ plants was weak after being stained with either Neu's or Wilson's reagent (Table 3). There was an absence of fluorescence in the root sections of the -Si-inoculated plants treated with both Neu's and Wilson's reagents at 24 and 32 dai (Figs. 2C and E; 3C and E) and the magnitudes of the reactions of the cells in the medulla and in the cortex were weak (Table 3). At 24 dai, strong yellow-orange fluorescence was observed in the phloem and lemon-yellow fluorescence was observed in the sclerenchyma and metaxylem vessels in the root sections of the $+\mathrm{Si}$-inoculated plants stained with Neu's reagent (Figs. 2D and 3D). With Wilson's reagent, orange-yellow autofluorescence was more pronounced around the phloem vessels and yellow fluorescence was more pronounced around the metaxylem vessels in the root sections of the $+\mathrm{Si}$-inoculated plants at 24 and 32 dai (Figs. $2 \mathrm{~F}$ and $3 \mathrm{~F}$ ). The magnitude of the reactions in the medulla and in the cortex of the root sections of the $+\mathrm{Si}$-inoculated plants treated with both Neu's and Wilson's reagents were strong at 24 and 32 dai (Table 3). Lignin was densely deposited in the cortex of the root sections of the $+\mathrm{Si}$-inoculated plants (Figs. $2 \mathrm{H}$ and $3 \mathrm{H}$ ) in comparison to the root sections of the $-\mathrm{Si}$-inoculated plants at

TABLE 1. Analysis of variance of the effects of silicon rates and sampling times on silicon $(\mathrm{Si})$ concentration in the roots and on the symptoms of Fusarium wilt in the roots $(\mathrm{SFWR})^{\mathrm{a}}$

\begin{tabular}{lcccc}
\hline & & \multicolumn{3}{c}{$F$ values } \\
\cline { 3 - 5 } Sources of variation & df & Ca & Si & SFWR \\
\hline Si rates & 1 & $42.52^{\text {ns }}$ & $62.32^{*}$ & $70.42^{*}$ \\
Sampling times (ST) & 1 & $102.25^{\text {ns }}$ & $119.58^{*}$ & $15.00^{*}$ \\
Si $\times$ ST & 1 & $2.46^{\text {ns }}$ & $3.39^{\text {ns }}$ & $1.67^{\text {ns }}$ \\
\hline a ns and ${ }^{*}$ indicate nonsignificant and significant at $1 \%$ probability, respectively.
\end{tabular}

TABLE 2. Silicon (Si) concentration in the roots and symptoms of Fusarium wilt in the roots (SFWR) of banana plants grown in soil amended $(+\mathrm{Si})$ or not amended (-Si) with $\mathrm{Si}$ and inoculated with Fusarium oxysporum f. sp. cubense $^{\mathrm{a}}$

\begin{tabular}{lcl}
\hline Factors & $\mathrm{Si}(\mathrm{dag} / \mathrm{kg})$ & SFWR \\
\hline Silicon rates & & \\
$\quad-\mathrm{Si}$ & 0.73 & 5.07 \\
$\quad+\mathrm{Si}$ & 0.99 & 4.00 \\
$t$ test & $18.47^{* *}$ & $7.22^{* *}$ \\
Sampling times & & \\
24 dai & 0.81 & 4.20 \\
32 dai & 0.90 & 4.70 \\
$t$ test & $2.02^{*}$ & $2.37^{*}$ \\
CV $(\%)$ & 14.98 & 9.80 \\
\hline
\end{tabular}

a ns, ${ }^{*}$, and ${ }^{* *}$ indicate nonsignificant and significant at 5 and $1 \%$ probability, respectively. $\mathrm{CV}=$ coefficient of variation, dai $=$ days after inoculation, $n=$ 20.
24 dai (Fig. 2G) and 32 dai (Fig. 3G). Dopamine was barely detected in the root sections of the -Si-inoculated plants at 24 and 32 dai using the lactic and glyoxylic acid stain (Figs. 2I and 3I), but strongly suspected to occur in the phloem and metaxylem vessels of the root sections of the $+\mathrm{Si}$-inoculated plants, as confirmed by the intense orange-yellow fluorescence at 24 (Fig. 2J) and 32 dai (Fig. 3J). The magnitude of the reactions of the cells in the medulla and in the cortex of the root sections of the $-\mathrm{Si}$ and $+\mathrm{Si}$ plants was weak for lignin and strongly suspected to occur for dopamine (Table 3). The cells in the medulla of the root sections of the samples for both the $-\mathrm{Si}$ - and $+\mathrm{Si}$-noninoculated plants was weak for both lignin and dopamine (Table 3). Neither lignin nor dopamine were detected in the cells in the cortex of the root sections of the samples obtained from either the $-\mathrm{Si}$ - or $+\mathrm{Si}$ noninoculated plants (Table 3 ).

\section{DISCUSSION}

The results of the present study confirm that Si can increase banana resistance to $F$. oxysporum $\mathrm{f}$. sp. cubense and provide novel evidence at the histochemical level of the strengthening of the cell walls in the roots of banana plants supplied with Si during infection by $F$. oxysporum f. sp. cubense. Banana plants are very efficient at accumulating $\mathrm{Si}$ in shoots through the uptake of monosilicic acid from the soil and, therefore, they become resistant to some plant pathogens $(18,19,23)$. The increase in the level of resistance of banana seedlings of the cultivar Maçã supplied with $\mathrm{Si}$, in comparison to plants not supplied with $\mathrm{Si}$, was associated with a higher Si concentration in the root tissues, confirming the results obtained by Fortunato et al. $(18,19)$. According to Chérif et al. (9), the root decay caused by Pythium ultimum and Pythium aphanidermatum was significantly reduced in cucumber plants

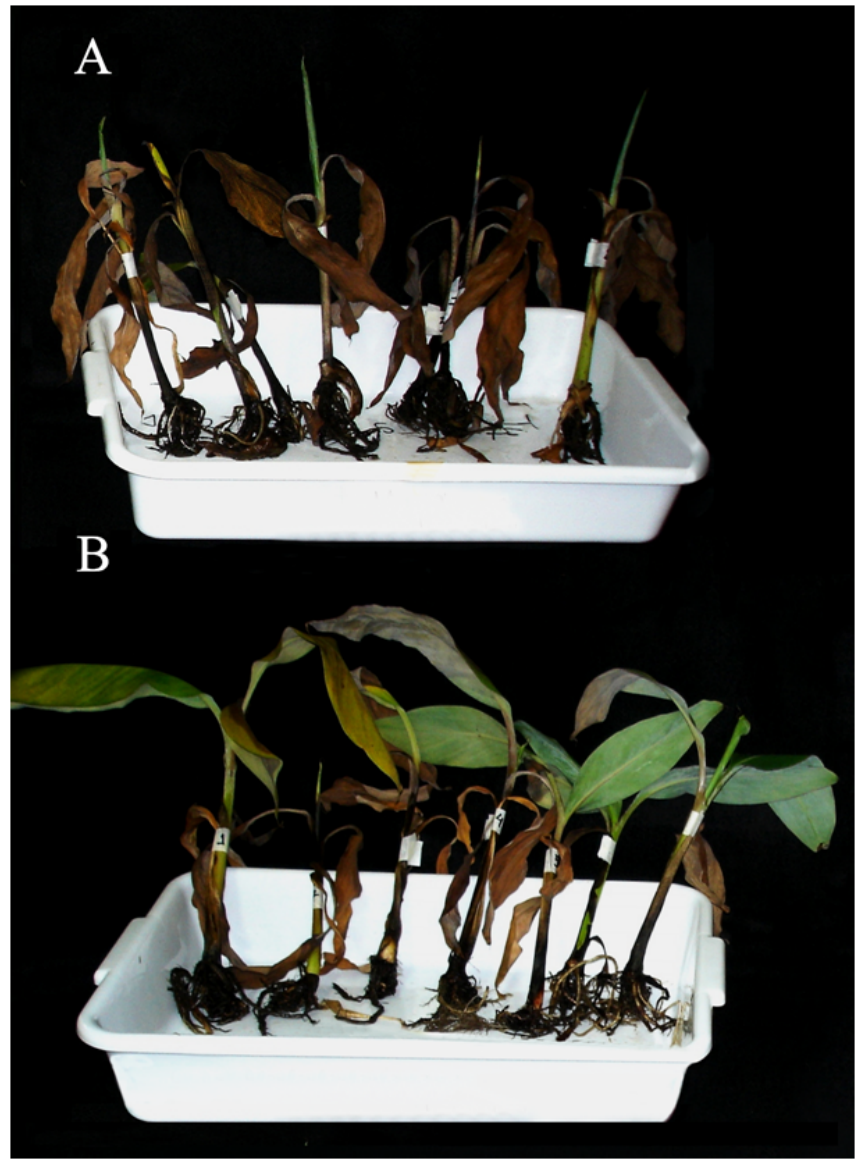

Fig. 1. Differences in Fusarium wilt shoot symptoms development for banana plants grown in soil $\mathbf{A}$, not amended or $\mathbf{B}$, amended with silicon. 

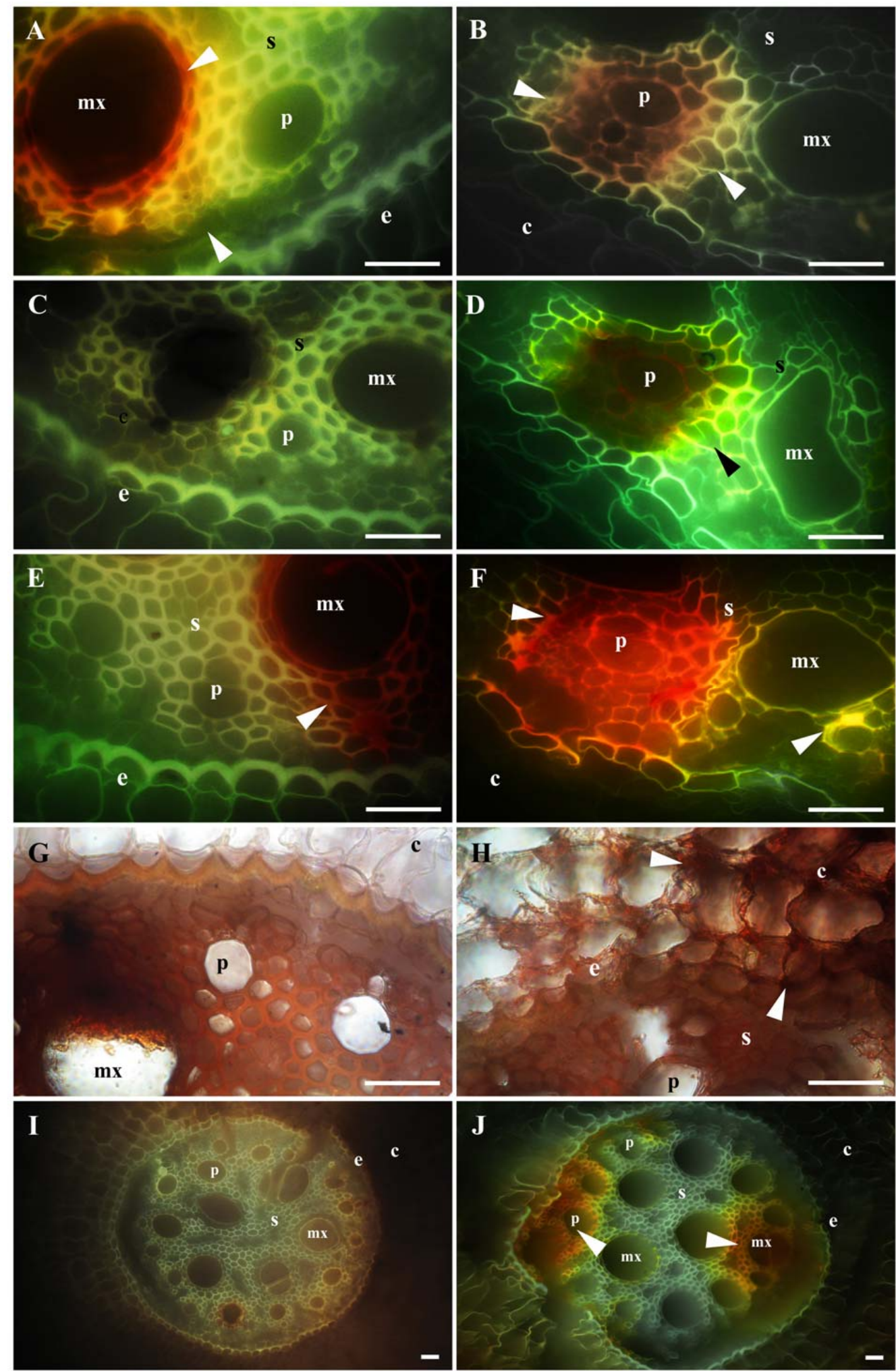

Fig. 2. Histochemical characterization of flavonoids, lignin, and dopamine in the roots of banana plants ('Maçã') B, D, F, H, and J, supplied (+Si) or A, C, E, G, and I, not supplied with silicon (-Si) at 24 days after inoculation with Fusarium oxysporum f. sp. cubense. A, Metaxylem vessels in the vascular bundles of the roots of the $-\mathrm{Si}$ plants exhibit yellow-orange autofluorescence (arrow). B, The roots of + Si plants exhibit slight yellow-orange autofluorescence (arrow) on the phloem and metaxylem vessels. C, No fluorescence was observed in the roots of the -Si plants after staining with Neu's reagent. D, Strong yellow-orange fluorescence (arrow) in the phloem to lemon-yellow fluorescence in the sclerenchyma and metaxylem vessels in the roots of the + Si plants after staining with Neu's reagent. E, Metaxylem vessels on the roots of $-\mathrm{Si}$ plants stained with Wilson's reagent exhibited slight orange fluorescence (arrow). F, Intense orangeyellow fluorescence (arrowheads) in the cells surrounding the vascular bundles of phloem and metaxylem vessels in the roots of +Si plants stained with Wilson's reagent. G, No evidence of lignin deposition in the roots of $-\mathrm{Si}$ plants after staining with phloroglucinol-HCl. $\mathbf{H}$, Strong lignin deposition in the cortex of roots of $+\mathrm{Si}$ plants stained with phloroglucinol-HCl (arrow). I, Absence of dopamine in the roots of -Si plants. J, Dopamine was strongly suspected to occur in the vascular bundles of phloem and metaxylem vessels (arrow) of roots of $+\mathrm{Si}$ plants as confirmed by orange-yellow fluorescence after staining with lactic acid + glyoxylic acid stain. $\mathrm{c}=$ cortex, $\mathrm{e}=$ endodermis, $\mathrm{mx}=$ metaxylem, $\mathrm{p}=$ phloem, and $\mathrm{s}=$ sclerenchyma. Bars $=50 \mu \mathrm{m}$. Two experiments were conducted with consistent results and the data presented represent the best experiment. 

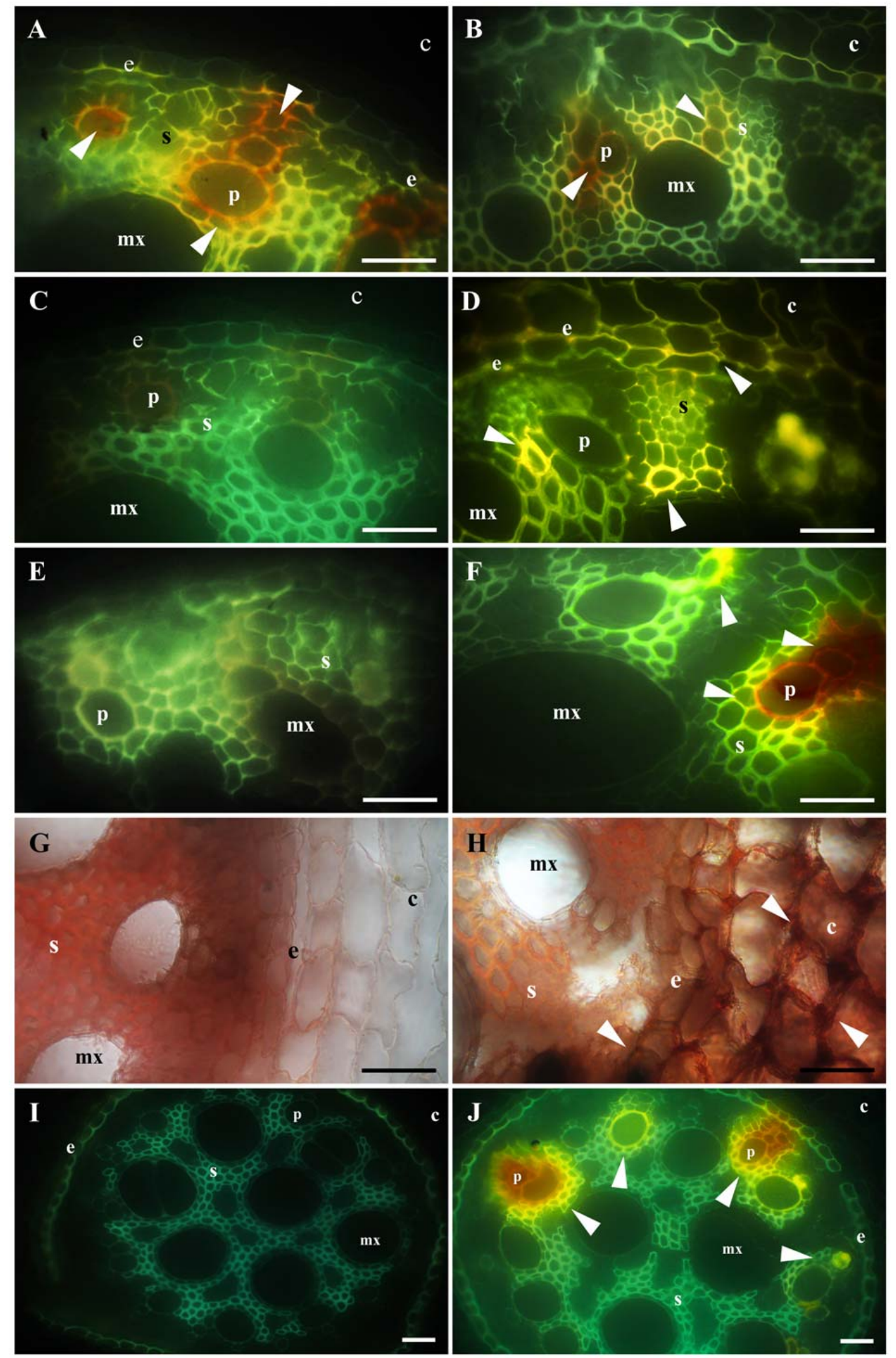

Fig. 3. Histochemical characterization of flavonoids, lignin, and dopamine in the roots of banana plants ('Maçã') B, D, F, H, and J, supplied (+Si) or A, C, E, G, and I, not supplied with silicon (-Si) at 32 days after inoculation with Fusarium oxysporum $\mathrm{f}$. sp. cubense. A, Strong yellow-orange autofluorescence (arrow) in the vascular bundles and in the sclerenchyma cells in the roots of -Si plants. B, Slight yellow-orange autofluorescence (arrow) near the phloem and metaxylem vessels in the roots of $+\mathrm{Si}$ plants. $\mathbf{C}$, Absence of fluorescence in the vascular bundles, sclerenchyma and endodermis cells in the roots of $-\mathrm{Si}$ plants stained with Neu's reagent. D, Strong yellow fluorescence in the roots of +Si plants stained with Neu's reagent (arrow). E, Slight orange-yellow fluorescence in the cells surrounding the phloem and metaxylem vessels and the sclerenchyma cells in the roots of -Si plants stained with Wilson's reagent. F, Strong orange-yellow fluorescence in the phloem vessels and in the sclerenchyma cells in the roots of $+\mathrm{Si}$ plants stained with Wilson's reagent (arrow). G, Absence of lignin deposition in the roots of -Si plants stained with phloroglucinol-HCl. H, Strong lignin deposition in the cortex of the roots of $+\mathrm{Si}$ plants stained with phloroglucinol-HCl (arrow). I, Absence of dopamine in the roots of -Si plants. J, Dopamine was strongly suspected to occur in the phloem and metaxylem vessels (arrow) of the roots of $+\mathrm{Si}$ plants as confirmed by orange-yellow fluorescence after staining with lactic acid + glyoxylic acid stain. $\mathrm{c}=$ cortex, $\mathrm{e}=\mathrm{endodermis,} \mathrm{mx}=\mathrm{metaxylem}, \mathrm{p}=$ phloem, and $\mathrm{s}=$ sclerenchyma. Bars $=50 \mu \mathrm{m}$. Two experiments were conducted with consistent results and the data presented represent the best experiment. 
supplied with Si. In addition, the area under the Phytophthora blight progress curve and the area under the wilting plants progress curve decreased in the roots of bell pepper plants supplied with $\mathrm{Si}$ (20). Huang et al. (24) observed that a high Si concentration in the roots and shoots of tomato plants contributed to reduce the severity of Fusarium crown and root rot due to a delay in the initial fungal infection on the roots and the movement of the fungus from roots to stems.

Phenolic compounds play an essential role in the performance of banana plants and their ability to defend against pathogen attack $(1,3,46,48,49)$. The activities of the defense enzymes phenylalanine ammonia-lyases (PAL), peroxidades (POX), and polyphenoloxidases (PPO), which are involved in the phenylpropanoid pathway, increased in plant tissues infected by a number of plant pathogens (28). According to Fortunato et al. (19), the symptoms of Fusarium wilt in the roots of banana plants supplied with $\mathrm{Si}$ decreased with increases in the concentrations of hydrogen peroxide, soluble phenolics, lignin, and greater activities of PAL, POX, PPO, chitinases, and $\beta$-1,3-glucanases. The potentiation of the phenylpropanoid pathway in plants supplied with $\mathrm{Si}$ as a strategy to protect them against pathogen infection has been very well documented in the literature $(17,26,41)$. Microscopic observations made by Rémus-Borel et al. (41) revealed that wheat plants supplied with $\mathrm{Si}$ showed fluorescence of phenolics in response to infection by $B$. graminis f. sp. tritici.

The deposition of flavonoids in plant cell walls is a strong biochemical defense in response to pathogen infection (28). High deposition of flavonoids in the roots of date palm plants was found to be associated with their increased resistance to infection by $F$. oxysporum f. sp. albedinis (14). Valette et al. (46) detected earlier deposition of flavonoids in the cell walls of the roots of plants of a partially resistant banana cultivar infected by Radopholus similis. In the present study, flavonoids were detected in the roots of $+\mathrm{Si}$ plants stained with Neu's and Wilson's reagents and infected by $F$. oxysporum f. sp. cubense. The strong autofluorescence detected in the root tissues of -Si plants at both 24 and 32 dai reflects the intense necrosis of cells due to extensive $F$. oxysporum f. sp. cubense colonization. It is known that during pathogenesis $F$. oxysporum f. sp. cubense damages cells by secreting lytic enzymes and nonselective toxins into colonized root tissues. These enzymes and nonselective toxins are also able to diffuse to adjacent healthy tissues and increase cellular damage (39). In contrast, reduced autofluorescence that was quenched over time in the roots of $+\mathrm{Si}$ plants may be associated with cell wall strengthening by both $\mathrm{Si}$ and lignin deposition, which somehow contributed to reducing the action of the lytic enzymes and nonselective toxins released by $F$. oxysporum f. sp. cubense.
Lignin, lignin polymers, and other phenolics play key roles in host response to pathogen infections due to their effect on the strength of cell walls (28), in addition to their effect in preventing or reducing the diffusion of lytic enzymes and nonselective toxins produced by the pathogens (15). Lignin was strongly deposited in the roots of banana plants in response to infection by $F$. oxysporum f. sp. cubense (1). The accumulation of phenolic-like compounds, including flavonoids and hydroxycinnamic acids, as well as the intense lignification and thickening of cell walls, restricted the colonization of Colletotrichum kahawae in coffee leaf tissues (29). In the roots of banana plants of a resistant cultivar infected by $R$. similis, lignin deposition was more intense in comparison to that in the roots of plants of a susceptible cultivar $(46,49)$. In the present study, strong lignification was detected in the cortex tissues of the roots of the +Si plants infected by $F$. oxysporum f. sp. cubense at 24 and 32 dai, in contrast to the $-\mathrm{Si}$ plants, which probably helped to delay $F$. oxysporum f. sp. $\mathrm{cu}$ bense colonization and created favorable conditions for the cells to active defensive response mechanisms.

Dopamine deposition in the root tissues of banana plants serves as a chemical barrier against pathogen spread (30) and the products of its degradation exhibit antimicrobial activity (24,35). Strong orange fluorescence, indicative of dopamine deposition, occurred in the cortex region of the root sections of plants from a resistant cultivar infected with $R$. similis (49). In the present study, intense yellow fluorescence, an indication of dopamine deposition, was observed in the root tissues of the $+\mathrm{Si}$ plants, especially at 32 dai, in contrast to the faint fluorescence observed in the root tissues of $-\mathrm{Si}$ plants.

Bananas from the cultivar Maçã are popular with consumers because of their flavor. However, its cultivation in areas where the soil is infested with $F$. oxysporum f. sp. cubense has become a considerable challenge to growers. The results of the present study support the notion that active Si uptake by banana roots is extremely important in enhancing host resistance to Fusarium wilt. To the best of our knowledge, it is also a novel finding that the phenylpropanoid pathway can be greatly potentiated by $\mathrm{Si}$ as a mechanism of resistance against $F$. oxysporum f. sp. cubense, even though the phenylpropanoid-derived products were not quantified using more refined techniques. This information may prove to be valuable in future research aimed at better understanding the mechanisms of banana resistance to Fusarium wilt facilitated by $\mathrm{Si}$ at the molecular and proteomic levels.

\section{ACKNOWLEDGMENTS}

F. Á. Rodrigues thanks the CNPq for his fellowship. A. A. Fortunato was supported by CAPES. We thank Multiplanta Tecnologia Vegetal Ltda for providing the banana seedlings for this study. This study was partially

TABLE 3. Histochemistry of phenolics in the roots of banana plants grown in soil amended $(+\mathrm{Si})$ or not amended (-Si) with silicon (Si) and noninoculated (control) or inoculated (24 and 32 days after inoculation [dai]) with Fusarium oxysporum f. sp. cubense ${ }^{\mathrm{a}}$

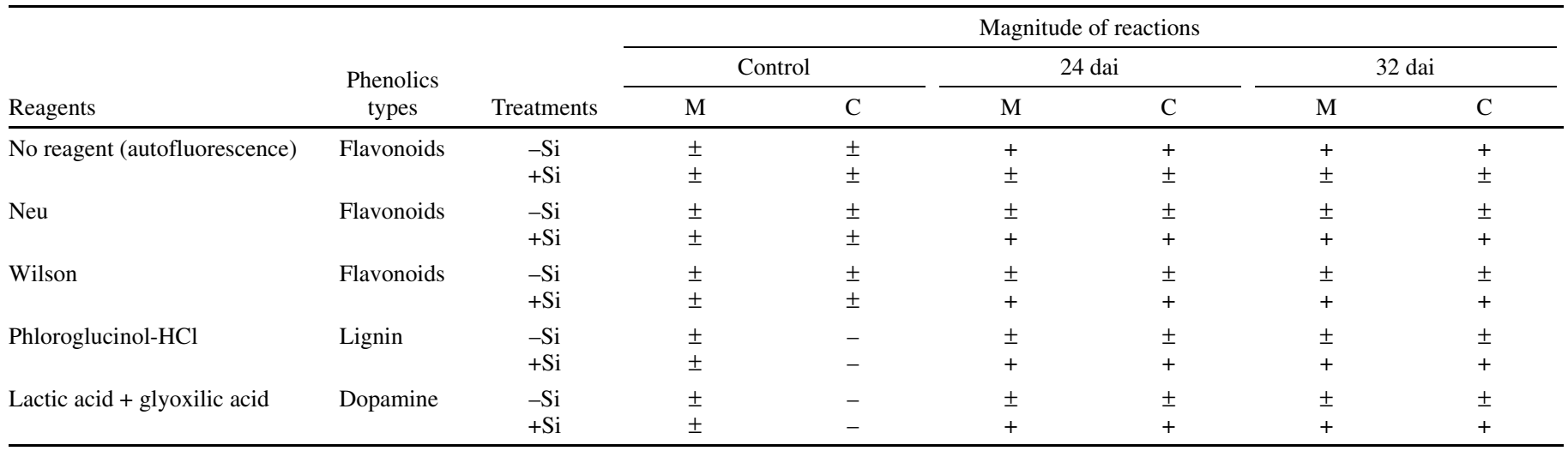

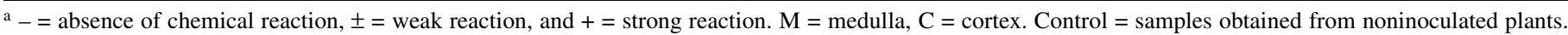

Two experiments were conducted with consistent results, and the data presented represent the best experiment. 
financed by CAPES, CNPq, FAPEMIG, and Harsco Minerais to F. Á. Rodrigues.

\section{LITERATURE CITED}

1. Ascensao, A. R., and Dubery, I. A. 2000. Panama disease: Cell wall reinforcement in banana roots in response to elicitors from Fusarium oxysporum f. sp. cubense race four. Phytopathology 90:1173-1180.

2. Ascensao, A. R., and Dubery, I. A. 2003. Soluble and wall-bound phenolics and phenolic polymers in Musa acuminate roots exposed to elicitors from Fusarium oxysporum f. sp. cubense. Phytochemistry 63:679-686.

3. Beckman, C. H., and Mueller, W. C. 1970. Distribution of phenols in specialized cells of banana root. Phytopathology 60:79-82.

4. Bélanger, R. R., Benhamou, N., and Menzies, J. G. 2003. Cytological evidence of an active role of silicon in wheat resistance to powdery mildew (Blumeria graminis f. sp. tritici). Phytopathology 93:402-412.

5. Bélanger, R. R., Bowen, P. A., Ehret, D. L., and Mezies, J. G. 1995. Soluble silicon: Its role in crop and disease management of greenhouse crops. Plant Dis. 79:329-336.

6. Brunings, A. M., Datnoff, L. E., Ma, J. F., Mitani, N., Nagamura, Y., Rathinasabapathi, B., and Kirst, M. 2009. Differential gene expression of rice in response to silicon and rice blast fungus Magnaporthe oryzae. Ann. Appl. Biol. 155:161-170.

7. Chain, F., Côté-Beaulieu, C., Bélzile, F., Menzies, J. G., and Bélanger, R. R. 2009. A comprehensive transcriptomic analysis of the effect of silicon on wheat plants under control and pathogen stress conditions. Mol. PlantMicrobe Interact. 22:1323-1330.

8. Chérif, M., Asselim, A., and Bélanger, R. R. 1994. Defense responses induced by soluble silicon in cucumber roots infected by Pythium spp. Phytopathology 84:236-242.

9. Chérif, M., Menzies, J. G., Benhamou, N., and Bélanger, R. R. 1992. Studies of silicon distribution in wounded and Pythium ultimum infected cucumber plants. Physiol. Mol. Plant Pathol. 41:371-385.

10. Dai, G. H., Andary, C., Mondolot-Cosson, L., and Boubals, D. 1995. Histochemical responses of leaves of in vitro plantlets of Vitis spp. to infection with Plasmopara viticola. Phytopathology 85:149-154.

11. Dai, G. H., Andary, C., Mondolot-Cosson, L., and Boubals, D. 1995. Histochemical studies on the interaction between three species of grapevine, Vitis vinifera, V. rupestris and V. rotundifolia and the downy mildew fungus, Plasmopara viticola. Physiol. Mol. Plant Pathol. 46:177-188.

12. Dannon, E. A., and Wydra, K. 2004. Interaction between silicon amendment, bacterial wilt development and phenotype of Ralstonia solanacearum in tomato genotypes. Physiol. Mol. Plant Pathol. 64:233-243.

13. Datnoff, L. E., Rodrigues, F. A., and Seebold, K. W. 2007. Silicon and plant disease. Pages 233-246 in: Mineral Nutrition and Plant Disease. L. E. Datnoff, W. H. Elmer, and D. M. Huber, eds. The American Phytopathological Society, St. Paul, MN.

14. Dihazi, A., Serghini, M. A., Jaiti, F., Daayf, F., Driouich, A., Dihazi, H., and El Hadrami, I. 2011. Structural and biochemical changes in salicylicacid-treated date palm roots challenged with Fusarium oxysporum f. sp. albedinis. J. Pathogens Article ID 280481.

15. Ewané, C. A., Lepoivre, P., de Lapeyre de Bellaire, L., and Lassois, L. 2012. Involvement of phenolic compounds in the susceptibility of bananas to crown rot. A review. Biotechnol. Agron. Soc. Environ. 16:393-404.

16. Fernandez, M. R., and Heath, M. C. 1989. Interactions of the non-host French bean plant (Phaseolus vulgaris) with parasitic and saprophytic fungi. III. Cytologically detectable responses. Can. J. Bot. 67:676-686.

17. Fleck, A. T., Nye, T., Repenning, C., Stahl, F., Zahn, M., and Schenk, M. K. 2011. Silicon enhances suberization and lignification in roots of rice (Oryza sativa). J. Exp. Bot. 62:2001-2011.

18. Fortunato, A. A., Rodrigues, F. A., Baroni, J. C. P., Soares, G. C. B., Rodriguez, M. A. D., and Liparini, O. P. 2012. Silicon suppresses Fusarium wilt development in banana plants. J. Phytopathol. 160:674-679.

19. Fortunato, A. A., Rodrigues, F. A., and Nascimento, K. J. T. 2012. Physiological and biochemical aspects of the resistance of banana plants to Fusarium wilt potentiated by silicon. Phytopathology 102:957-966.

20. French-Monar, R. D., Rodrigues, F. A., Korndörfer, G. H., and Datnoff, L. E. 2010. Silicon suppresses Phytophthora blight development on bell pepper. J. Phytopathol. 158:554-560.

21. Gomez, K. A., and Gomez, A. A. 1994. Statistical Procedures for Agricultural Research. 2nd ed. John Wiley, New York.

22. Heine, G., Tikun, G., and Horst, W. L. 2007. The effect of silicon on the infection by and spread of Pythium aphanidermatum in single roots of tomato and bitter gourd. J. Exp. Bot. 58:569-577.

23. Henriet, C., Draye, X., Oppitz, I., Swennen, R., and Delvaux, B. 2006. Effects, distribution and uptake of silicon in banana (Musa spp.) under optimal conditions. Plant Soil 287:359-374.

24. Huang, C.-H., Roberts, P. D., and Datnoff, L. E. 2011. Silicon suppresses
Fusarium crown and root rot of tomato. J. Phytopathol. 159:546-554.

25. Kanazawa, K., and Sakakibara, H. 2000. High content dopamine, a strong antioxidant, in Cavendish banana. J. Agric. Food Chem. 48:844-848.

26. Koga, H., Zeyen, R. J., Bushnell, W. R., and Ahlstrand, G. G. 1988. Hypersensitive cell death, autofluorescence, and insoluble silicon accumulation in barley leaf epidermal cells under attack by Erysiphe graminis f. sp. hordei. Physiol. Mol. Plant Pathol. 32:395-409.

27. Lanning, F. C. 1963. Silicon in rice. J. Agric. Food Chem. 11:435-437.

28. Lattanzio, V., Lattanzio, V. M., and Cardinali, A. 2006. Role of phenolics in the resistance mechanisms of plants against fungal pathogens and insects. Phytochem. Adv. Res. 661:23-67.

29. Loureiro, A., Nicole, M. R., Várzea, V., Moncada, P., Bertrand, B., and Silva, M. C. 2012. Coffee resistance to Colletotrichum kahawae is associated with lignification, accumulation of phenols and cell death at infection sites. Physiol. Mol. Plant Pathol. 77:23-32.

30. Mace, M. E. 1963. Histochemical localization of phenols in healthy and diseased banana roots. Physiol. Plant 16:915-925.

31. Matern, U., Grimmig, B., and Kneusel, R. E. 1995. Plant cell wall reinforcement in the disease-resistance response: Molecular composition and regulation. Can. J. Bot. 73:511-517.

32. Matern, U., and Kneusel, R. E. 1988. Phenolic compounds in plant disease resistance. Phytoparasitica 16:153-170.

33. Mohamed, A. A., Mak, C., Liew, K. W., and Ho, Y. W. 1999. Early evaluation of banana plants at nursery stage for Fusarium wilt tolerance. In: Banana Fusarium Wilt Management: Towards Sustainable Cultivation. A. B. Molina, N. K. Masdek, and K. W. Liew, eds. Procedures of International Workshop on the Banana Fusarium Wilt Disease, Malaysia.

34. Monties, B. 1989. Lignins. Pages 113-157 in: Methods in Plant Biochemistry, Vol. 1. P. P. Dey and J. B. Harbone, eds. Academic Press, London, UK.

35. Muirhead, I. F., and Jones, D. R. 2000. Fungal diseases of banana fruit. Post-harvest diseases. In: Diseases of Banana, Abaca and Ensete. D. R. Jones, ed. CAB International, Wallingford, UK.

36. Neu, R. 1956. A new reagent for differentiating and determining flavones on paper chromatograms. Naturwissenschaften 43:82.

37. Nicholson, R. L., and Hammerchmidt, R. 1992. Phenolics compounds and their role in disease resistance. Annu. Rev. Phytopathol. 30:369-389.

38. Ploetz, R. C. 2006. Fusarium wilt of banana is caused by several pathogens referred to as Fusarium oxysporum f. sp. cubense. Phytopathology 96:653-656

39. Ploetz, R. C., and Pegg, K. G. 2000. Fungal diseases of root, corm and pseudostem. Pages 143-159 in: Diseases of Banana, Abaca and Ensete. D. Jones, ed. CAB International, Wallingford, UK.

40. Ranathunge, K., Thomas, R. H., Fang, X., Peterson, C. A., Gijzen, M., and Bernards, M. A. 2008. Soybean root suberin and partial resistance to root rot caused by Phytophthora soiae. Phytopathology 98:1179-1189.

41. Rémus-Borel, W., Menzies, J. G., and Bélanger, R. R. 2005. Silicon induces antifungal compounds in powdery mildew-infected wheat. Physiol. Mol. Plant Pathol. 66:108-115.

42. Rodrigues, F. A., Benhamou, N., Datnoff, L. E., Jones, J. B., and Bélanger, R. R. 2003. Ultrastructural and cytochemical aspects of silicon mediated rice blast resistance. Phytopathology 93:535-546.

43. Rodrigues, F. A., Jurick, W. M., Datnoff, L. E., Jones, J. B., and Rollins, J. A. 2005. Silicon influences cytological and molecular events in compatible and incompatible rice-Magnaporthe grisea interactions. Physiol. Mol. Plant Pathol. 66:144-159.

44. Rodrigues, F. A., McNally, D. J., Datnoff, L. E., Jones, J. B., Labbé, C., Benhamou, N., Menzies, J. G., and Bélanger, R. R. 2004. Silicon enhances the accumulation of diterpenoid phytoalexins in rice: A potential mechanism for blast resistance. Phytopathology 94:177-183.

45. Shiraishi, T., Yamaoka, N., and Kunoh, H. 1989. Association between increased phenylalanine ammonia-lyase activity and cinnamic acid synthesis and the induction of temporary inaccessibility caused by Erysiphe graminis primary germ tube penetration of the barley leaf. Physiol. Mol. Plant Pathol. 34:75-83.

46. Valette, C., Andary, C., Geiger, J. P., Sarah, J. L., and Nicole, M. 1998. Histochemical and cytochemical investigations of phenols in roots of banana infected by the burrowing nematode Radopholus similis. Phytopathology 88:1141-1148.

47. Vermeire, M. L., Kablan, L., Dorel, M., Delvaux, B., Risède, J. M., and Legrève, A. 2011. Protective role of silicon in the banana-Cylindrocladium spathiphylli pathosystem. Eur. J. Plant Pathol. 131:621-630.

48. Wuyts, N., de Waele, D., and Swennen, R. 2006. Extraction and partial characterization of polyphenol oxidase from banana (Musa acuminata, Gande naine) roots. Plant Physiol. Biochem. 44:308-314.

49. Wuyts, N., Lognay, G., Verscheure, M., Marlier, M., de Waele, D., and Swennen, R. 2007. Potential physical and chemical barriers to infection by the burrowing nematode Radopholus similis in roots of susceptible and resistant banana (Musa spp.). Plant Pathol. 56:878-890.

50. Yoshida, S., Ohnishi, Y., and Kitagishi, K. 1962. Chemical forms, mobility and deposition of silicon in rice plant. Soil Sci. Plant Nutr. 8:15-21. 